\title{
Melatonin in Edible and Non-Edible Plants
}

\section{Yenilebilen ve Yenilemeyen Bitkilerde Melatonin}

\author{
Ufuk KOCA ÇALIŞKAN*, Ceylan AKA, Emrah BOR \\ Gazi University, Faculty of Pharmacy, Department of Pharmacognosy, Ankara, Turkey
}

\begin{abstract}
The concept of melatonin has become more important recently both in plants and in human who utilize plants for nutritional and health purposes. Melatonin, synthesized from L-tryptophan by enzyms, protects plants against difficult conditions. People have consumed these plants for their antioxidant, immunomodulator, antiinflammatory and anticancer effects. In parts of edible and non-edible plants, levels of melatonin are determined by cyclodextrin-modified micellar electrokinetic chromatography, enzyme-linked immuno sorbent assay, radioimmunoassay, highperformance liquid chromatography, liquid chromatography with electrochemical detection, liquid chromatography with fluorimetric detection, liquid chromatography-mass spectrometry, and liquid chromatography-ultraviolet spectrophotometry. In this review, biosynthesis of melatonin in both animal and plants, function of melatonin in plant kingdom, especially in medicinal/edible and nonedible plants, and detection of phytomelatonin content in those plants are presented.
\end{abstract}

Key words: Melatonin, phytomelatonin, activity of melatonin

öz

Bitkilerde melatonin kavramı, son yıllarda, hem bitkiler hem de beslenme ve sağlığı koruma amacıyla bitkileri kullanan insanlar için oldukça önemli olmuştur. Enzimler aracılığıyla L-triptofandan sentezlenen melatonin bitkiyi zorlu koşullara karşı korumaktadır. İnsanlar antioksidan, immünomodülatör, antienflamatuvar ve antikanser etkilerinden dolayı bu bitkileri kullanmaktadır. Yenilebilen ve yenilemeyen bitki kısımlarında siklodeskstrinle modifiye edilmiş miseller elektrokinetik kromatografi, enzim bağlı immünosorban deneyi, radyoimmün test, yüksek performanslı sıvı kromatografisi, elektrokimyasal algılamalı sıvı kromatografisi, florometrik algılamalı sıvı kromatografisi, sıvı kromatografisi-kütle spektrometrisi ve sıvı kromatografisi-ultraviyole spektrofotometri yöntemleri ile tespit edilmiştir. Bu derlemede, melatoninin hem hayvanlarda hem de bitkilerde biyosentezi, özellikle tıbbi/yenilebilen ve yenilemeyen bitkilerde melatoninin fonksiyonu ve bu bitkilerde fitomelatonin içeriği sunulmuştur.

Anahtar kelimeler: Melatonin, fitomelatonin, melatonin etkisi

\section{INTRODUCTION}

Melatonin ( $N$-acetyl-5-methoxytryptamine) means melanophore-

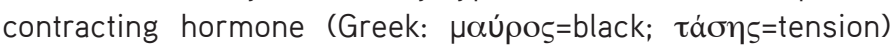
firstly was isolated from bovine's pineal gland in 1958.1.2 It is a neurohormone secreted by the pineal gland and a derivative of serotonin. ${ }^{3}$ Serotonin is a monoamine neurotransmitter and one of the precursors (Figure 1), whereas L-tryptophan, like serotonin is the common precursor of melatonin biosynthesis. ${ }^{4,5}$ Both have many influences on health of animal and human being, such as serotonin is used against depression ${ }^{6}$ and also affects behaviours and inward. ${ }^{7}$ Secretion of melatonin increases in the dark on the contrary of light, seasonal and physiological alteration effect levels of melatonin ${ }^{8,9}$ for that reason that has been studied for its hormon like effects and its biological activities for decades.

Although melatonin was described in organisms such as bacteria, fungi, algae, and vertebrates ${ }^{10}$ it was notified in plants at the end of 1994.1,12 Increasing number of studies have proved that there was melatonin in different parts (seed, fruit, leaf, root etc.) of plants and in so much as medicinal herbs..$^{13} \mathrm{~A}$ major role of melatonin in plants have been discovered that protects plants against damages of changing climate. ${ }^{14}$

\section{Biosynthesis of melatonin}

Melatonin is synthesised not only in bone marrow cells ${ }^{15}$ but also in retina. ${ }^{16,17}$ Thus it is both a hormone and tissue factor. ${ }^{10}$ The presence of melatonin was detected in egg, biological fluids like plasma, milk, by developed methods, such as liquid chromatography (LC) with fluorimetric detection, and LCtandem mass spectrometry (LC-MS/MS). ${ }^{18,19}$ Biosynthesis of melatonin is explained enzymatically from the essential amino acid precursor tryptophan to melatonin. The synthesis includes four different enzymes. The first one is tryptophan hydroxylase (TPH), which forms 5-hydroxytryptophan from tryptophan; the second is aromatic amino acid decarboxylase which forms 
serotonin from 5-hydroxytryptophan; the third is arylalkylamine $\mathrm{N}$-acetyl-transferase (AANAT), which forms $\mathrm{N}$-acetylserotonin from serotonin; and the last one is $N$-acetylserotonin $O$-methyltransferase (ASMT), which forms the final step to melatonin (Figure 2). AANAT and ASMT is considered that they were speed limiting enzymes. 4,20

\section{Biological activity of melatonin}

A major role of melatonin is the antioxidant function with free radicals (reactive oxygen species) and reactive nitrogen species scavenging activity ${ }^{21-25}$ thus has protective effect against ultraviolet (UV) radiations induced damages. ${ }^{26}$ Consequently, melatonin can be used for healing of muscle diseases, Parkinson and Alzheimer's due to antioxidant and neuroprotective affects. ${ }^{27-31}$ Melatonin is widely used for sleep disorders such as jetlag and insomnia. ${ }^{32}$ Its administration can relieve daytime and overnight sleep. ${ }^{33,34}$ Clinical and in vivo studies showed that melatonin decreased symptoms of depression ${ }^{35-37}$ moreover has immunomodulator function. ${ }^{38,39}$ It regulates immuno fuctions by means of production interleukin (IL)-2, IL-6, IL-12 and interferon gamma. ${ }^{40,41,42}$ An in vivo study
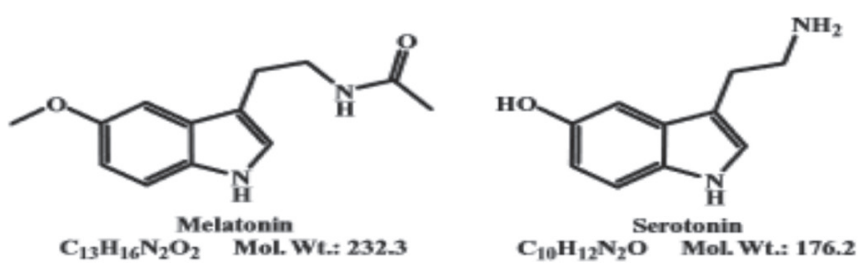

Figure 1. Structure of melatonin and serotonin

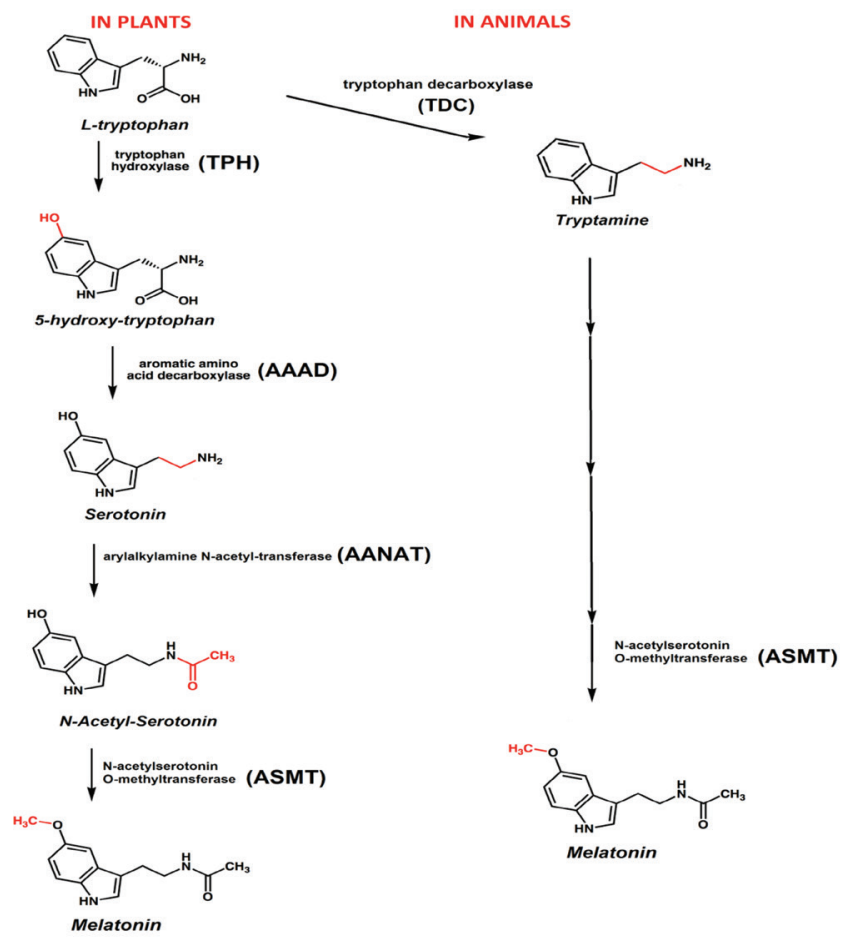

Figure 2. Modified synthesis of melatonin from tryptophan

TPH: Tryptophan hydroxylase, TDC: Tryptophan decarboxylase, AAAD: Aromatic amino acid decarboxylase, AANAT: Arylalkylamine $N$-acetyl- transferase, ASMT: $\mathrm{N}$-acetylserotonin $\mathrm{O}$-methyltransferase showed that melatonin have potential anticonvulsant activity. ${ }^{43}$ Melatonin effects vasculer system. ${ }^{44}$ Studies showed that melatonin suppress proliferation of cancer cell line and induces apoptosis tumor cell and also it is promising for the treatment of prostat cancer, and breast cancers. ${ }^{25,45-53}$ A study has also emitted that melatonin can be effective on malaria. ${ }^{54}$

\section{Melatonin in plants-phytomelatonin}

First evidence of the presence of melatonin in organisms was obtained in Lingulodinium polyedrum (syn. Gonyaulax polyedra) and Pyrocystis acuta, which were unicellular organisms. Scientists detected melatonin metabolite 5-methoxytryptamine and the melatonin analogue $N, N$-dimethyl-5-methoxytryptamine in those living organisms. ${ }^{55-57}$ By following studies melatonin was determined in the members of alga, bacteria, fungi, plant families. Level of melatonin, although differs from plant to plant, that was observed higher than level of melatonin in animal blood. ${ }^{58-60}$ Melatonin level varies both from plant to plant and also tissues/organs of same plant, moreover, temperature, $\mathrm{pH}$, effects of present metal ions's, sensitivity of analytics and extraction methods cause these diversities. For example, melatonin of Datura metel L. (devil's trumpet) differed from flowers and leaves. In addition, melatonin of Lycopersicon esculentum Mill. varied by region.11,61-64 Presence of melatonin in different plants were shown in Table 1.

\section{Biosynthesis of phytomelatonin}

Plant melatonin biosynthesis pathway firstly was determined owing to Hypericum perforatum L. (St John's wort).4,59 Synthesis in plants is complicated on the contrary in animals (Figure 2). Initial enzyme is tryptophan decarboxylase (TDC) instead of TPH. TDC forms tryptamine from essential amino acid tryptophan. The last enzyme is ASMT (Figure 2) ${ }^{65,66}$ Plants take melatonin also by their roots apart from biosynthesis. ${ }^{67,68}$ Although its biosynthetic pathway and metabolic mechanisms are unclear, the presence of melatonin in plants is a wide concept. ${ }^{69}$

\section{Functions of phytomelatonin}

Melatonin has roles in plants similar to animals, that protects plants against extreme conditions such as temperature change, UV exposure, environmental pollution, toxins, drought oxidative and (a) biotic stress. Exogenous melatonin applied to Arabidopsis (thale cress) leaves has demostrated preservative potency against high salinity, cold and dryness, additionally plant has developed tolrerance biotic and abiotic stresses. ${ }^{70}$ Corn embriyo proteome was improved due to exogenous melatonin. ${ }^{71}$ Moreover, harmful effects of salt diminished by melatonin in faba bean. ${ }^{72}$ Conservation aspects of melatonin were studied in a variety of plants such as wheat, oat, barley, canary grass, tobacco, Chinese liquorice, soybean, cucumber, tomato. ${ }^{14,67,73-79}$ The studies also has shown that melatonin has regulatory role in growth of thale cress, specially growth of flowers and fruits. ${ }^{80}$ Reports, which investigated effect of exogenous melatonin on both tomato's and maize's seeds, have confirmed this case too. ${ }^{78,81}$ Melatonin plays an important role to maintain the vitality of the plants. ${ }^{82}$ 
Table 1. Levels of melatonin in plants with the detection methods

Family

Actinidiaceae

Amaranthaceae

Amaryllidaceae

Amaryllidaceae

Anacardiaceae

Anacardiaceae

Anacardiaceae

Apiaceae

Apiaceae

Apiaceae

Apiaceae

Apiaceae

Apiaceae

Arecaceae

Asparagaceae

Asparagaceae

Asteraceae

Asteraceae

Asteraceae

Asteraceae

Asteraceae

Araceae

Araceae

Brassicaceae

Brassicaceae

Brassicaceae

Brassicaceae

Brassicaceae

Brassicaceae

Brassicaceae

Bromeliaceae

Caprifoliaceae

Caprifoliaceae

Caprifoliaceae

Caprifoliaceae

Cucurbitaceae

Ephedraceae

Ephedraceae

Fabaceae

Fabaceae

Fabaceae

Fabaceae

Juglandaceae
Latin name

Actinidia chinensis Planch.

Basella alba $L$

Allium cepa L.

Allium fistulosum $L$.

Pistacia lentiscus $L$.

Pistacia lentiscus $L$.

Pistacia palaestina Boiss.

Angelica keiskei Koidz.

Apium graveolens $L$.

Coriandrum sativum $L$.

Daucus carota L.

Foeniculum vulgare Mill.

Pimpinella anisum $L$.

Phoenix dactylifera $L$.

Asparagus officinalis $L$.

Ophiopogon japonicus (L.f.) Ker Gawl.

Glebionis coronari (L.) Cass. ex Spach

Dendranthema morifolium (Ramat.) Tzvelev

Helianthus annuus $L$.

Petasites japonicus F. Schmidt

Silybum marianum (L.) Gaertn.

Colocasia esculenta (L.) Schott

Peltandra virginica (L.) Raf. ex Schott

Arabidopsis spp.

Brassica campestris L.

Brassica hirta Moench

Brassica nigra (L.) W. D. J. Koch

Brassica oleracea $L$.

Raphanus sativus $L$.

Raphanus sativus $L$.

Ananas comosus (L.) Merr.

Lonicera etrusca hort. ex Tausch

Lonicera etrusca hort. ex Tausch

Lonicera japonica Thunb.

Viburnum tinus $L$.

Cucumis sativus $L$.

Ephedra campylopoda C. A. Mey.

Ephedra campylopoda C.A.Mey.

Glycyrrhiza uralensis Fisch. ex DC.

Lupinus albus $L$.

Medicago sativa $L$.

Trigonella foenum-graceum $L$.

Juglans nigra $L$.
Part

Fruit

Leaf

Bulb

Bulb

Leaf

Whole fruit

Leaf

Leaf and stem of leaf

Seed

Seed

Root

Seed

Seed

Whole fruit

Shoot

Whole plant

Leaf

Whole plant

Seed

Shoot

Seed

Tuber

Whole plant

Leaf

Leaf

Seed

Seed

Leaf

Whole plant

Root

Fruit

Leaf

Seed

Whole plant

Leaf

Fruit

Leaf

Seed

Whole plant

Seed (Cotyledone)

Seed

Seed

Fruit

Ref.

Quantity

$\mathrm{pg} / \mathrm{g}$

$24 \quad$ RIA 61

39 RIA

RIA

RIA

ELISA

61

32

86

581

ELISA

ELISA

498

RIA

HPLC-ECD

HPLC-ECD 97

7

RIA

55

HPLC-ECD 97

28

7

HPLC-ECD 97

469 ELISA $\quad 96$

198

HPLC-FD-MS 90

$417 \quad$ RIA $\quad 61$

29

HPLC-FD-MS 90

HPLC-ECD 97

RIA 61

HPLC-ECD 97

2

50

RIA

61

HPLC-FD-MS 90

SPE, CD-ME- 98

$\mathrm{KC}$

$548 \pm 26$

657 RIA

HPLC-ECD 97

HPLC-ECD 97

129

$107 \quad$ RIA

485 HPLC-FD-MS 90

$13 \quad$ RIA $\quad 61$

$36 \quad$ RIA $\quad 61$

$521 \quad$ ELISA 96

$403 \quad$ ELISA 96

$140 \quad$ HPLC-FD-MS 90

613

613

ELISA

25 RIA

RIA 61

ELISA

ELISA 96

379

HPLC-FD-MS 90

HPLC-FD 99, 100

HPLC-ECD 97

HPLC-ECD 97

HPLC-ECD 101


Table 1. Continue

\begin{tabular}{|c|c|c|c|c|c|c|}
\hline Lamiaceae & Salvia miltiorrhiza Bunge & Whole plant & 187 & & HPLC-FD-MS & 90 \\
\hline Lauraceae & Laurus nobilis $L$. & Leaf & & 8331 & ELISA & 96 \\
\hline Lauraceae & Laurus nobilis L. & Whole fruit & & 3710 & ELISA & 96 \\
\hline Lauraceae & Laurus nobilis $L$. & Seed & & 6060 & ELISA & 96 \\
\hline Lauraceae & Laurus nobilis $L$. & Pulp & & 1820 & ELISA & 96 \\
\hline Liliaceae & Asparagus aphyllus L. & Leaf & & 142 & ELISA & 96 \\
\hline Liliaceae & Ruscus aculeatus $L$. & Leaf & & 954 & ELISA & 96 \\
\hline Liliaceae & Smilax aspera L. & Leaf & & 443 & ELISA & 96 \\
\hline Linaceae & Linum usitatissimum L. & Seed & 12 & & HPLC-ECD & 97 \\
\hline Meliaceae & Melia azedarach L. & Leaf & & 1579 & ELISA & 96 \\
\hline Meliaceae & Melia azedarach L. & Whole fruit & & 585 & ELISA & 96 \\
\hline Moraceae & Morus alba L. & Leaf & 1510 & & HPLC-FD-MS & 90 \\
\hline Moraceae & Morus spp. & Leaf & & 990 & ELISA & 96 \\
\hline Moraceae & Ficus carica L. & Leaf & & 12.915 & ELISA & 96 \\
\hline Moraceae & Ficus carica L. & Whole fruit & & 3963 & ELISA & 96 \\
\hline Myrtaceae & Feijoa sellowiana (O. Berg) O. Berg & Leaf & & 1529 & ELISA & 96 \\
\hline Myrtaceae & Myrtus communis $L$. & Leaf & & 291 & ELISA & 96 \\
\hline Myrtaceae & Myrtus spp. & Leaf & & 490 & ELISA & 96 \\
\hline Oleaceae & Olea europaea L. & Leaf & & 4306 & ELISA & 96 \\
\hline Oleaceae & Olea europaea $L$. & Pulp & & 532 & ELISA & 96 \\
\hline Oleaceae & Phillyrea latifolia L. & Leaf & & 6337 & ELISA & 96 \\
\hline Oleaceae & Phillyrea latifolia L. & Seed & & 439 & ELISA & 96 \\
\hline Oleaceae & Phillyrea latifolia L. & Pulp & & 589 & ELISA & 96 \\
\hline Papaveraceae & Papaver somniferum $L$. & Seed & 6 & & HPLC-ECD & 97 \\
\hline Poaceae & Avena sativa $L$. & Seed & & 1796 & RIA & 61 \\
\hline Poaceae & Avena sativa $L$ & Seed & $90.6 \pm 7.7$ & & HPLC-ECD & 102 \\
\hline Poaceae & Hordeum vulgare $L$. & Seed & & 378 & $\mathrm{RIA}$ & 61 \\
\hline Poaceae & Hordeum vulgare $L$. & Seed & $82.3 \pm 6.0$ & & HPLC-ECD & 102 \\
\hline Poaceae & Hordeum vulgare $L$. & Seed & $0.09 \pm 0.01$ & & HPLC-FD & 99 \\
\hline Poaceae & Hordeum vulgare $L$. & Seed & $0.58 \pm 0.05$ & & HPLC-FD & 99 \\
\hline Poaceae & Oryza sativa L. subsp. japonica Shig. Kato & Seed & 1006 & & $\mathrm{RIA}$ & 61 \\
\hline Poaceae & Phalaris canariensis L. & Seed & $26.7 \pm 2.2$ & & HPLC-ECD & 102 \\
\hline Poaceae & Triticum spp. & Seed & $124.7 \pm 14.9$ & & HPLC-ECD & 102 \\
\hline Poaceae & Triticum spp. & Seed & 2 & & HPLC-UV & 102 \\
\hline Poaceae & Triticum spp. & Seed & 4 & & HPLC-UV & 102 \\
\hline Poaceae & Zea mays $L$. & Seed & & 1366 & RIA & 61 \\
\hline Poaceae & Zea mays $L$. & Seed & $\begin{array}{l}0.011 * 10-9- \\
2.034 * 10-9\end{array}$ & & HPLC & 103 \\
\hline Resedaceae & Ochradenus baccatus Delile & Leaf & & 474 & ELISA & 96 \\
\hline Resedaceae & Ochradenus baccatus Delile & Whole fruit & & 488 & ELISA & 96 \\
\hline Rhamnaceae & Rhamnus alaternus $L$. & Leaf & & $306 \pm 75$ & ELISA & 96 \\
\hline Rhamnaceae & Rhamnus palaestina Boiss. & Whole fruit & & 907 & ELISA & 96 \\
\hline Rhamnaceae & Rhamnus palaestina Boiss. & Seed & & 547 & ELISA & 96 \\
\hline
\end{tabular}


Table 1. Continue

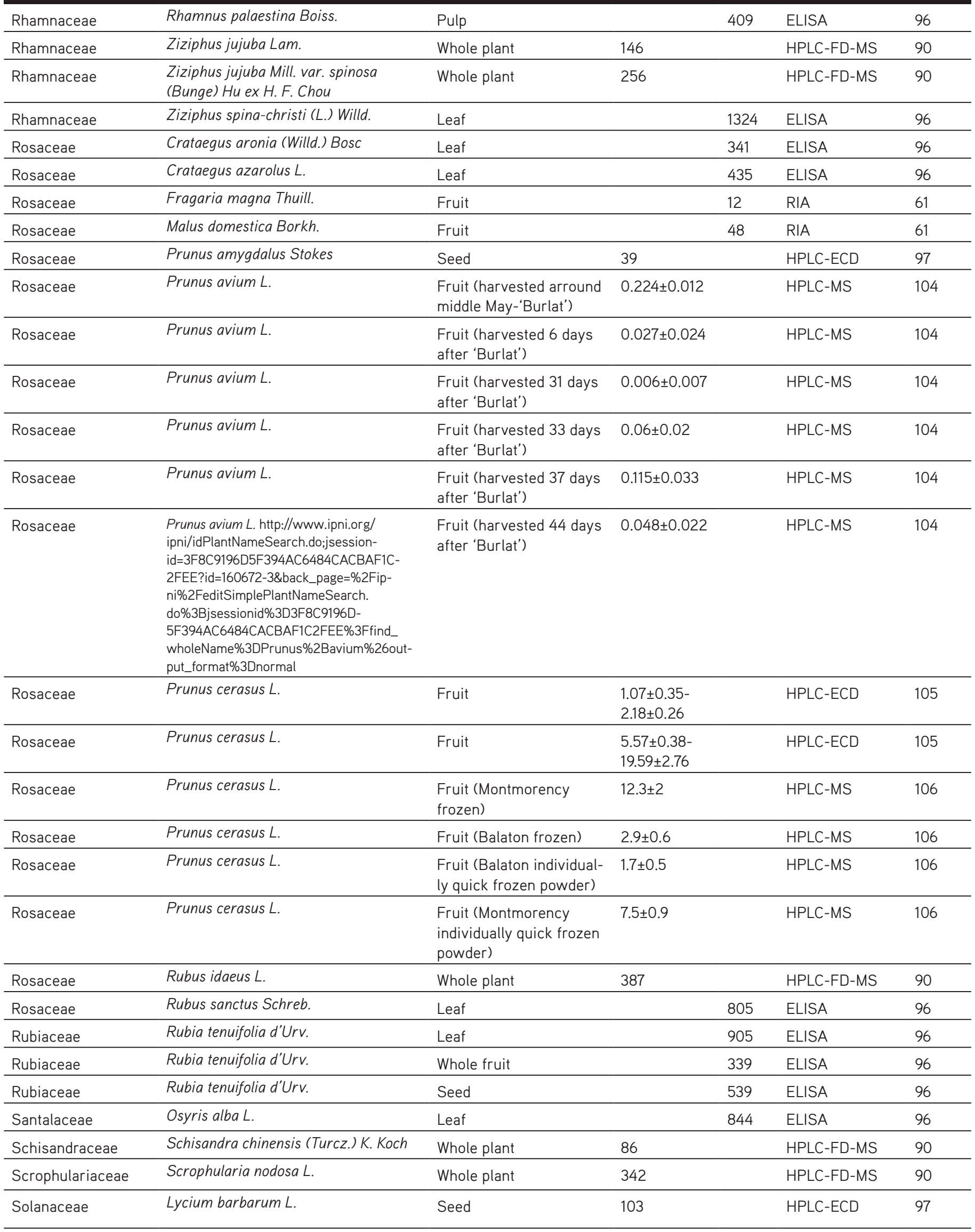


Table 1. Continue

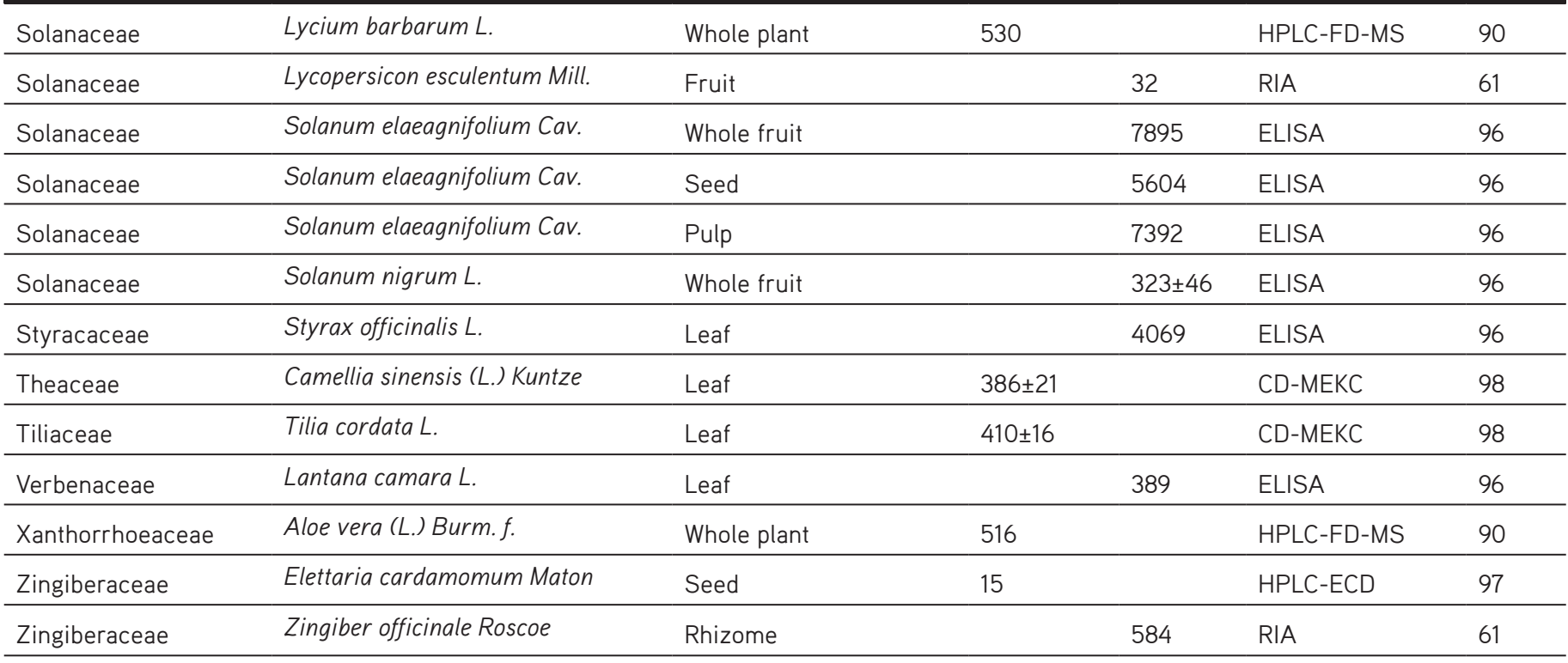

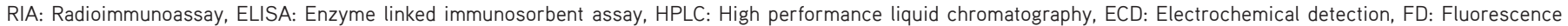
detector, MS: Mass spectrometry, SPE: Solid phase extraction, CD: Cyclodextrin, MEKC: Micellar electrokinetic chromatography, UV: Ultraviolet

\section{Phytomelatonin in diets}

The most popular drinks, which are tea, coffee, beer and wine contain melatonin. Not only melatonin but also its isomers (tryptophan-ethylester) were determined in wine and bread. ${ }^{83-85}$ A study reported that regular coffee consumption remarkably decreases the prevalence of human prostate cancer. ${ }^{86-88}$ Scientists introduced that melatonin in wine besides the other secondary metabolites, had protective effect against heart injury. ${ }^{89}$ Melatonin was determined high amount in Chinese medicinal herbs. Some of them were Viola philippica Cav., Uncaria rhynchophylla Miq., Morus alba L. and Phellodendron amurense Rupr. ${ }^{90}$ In Mediterranean diet, melatonin was found in some foods. It'is thought that melatonin can have positive effects on health via synergic effects with other compounds. ${ }^{91}$ Dietary suplement/melatonin supplement preparations have been consumed for different purposses by people mostly in Europe and the United States than the other countries. ${ }^{92}$

\section{Determination of phytomelatonin levels in plants}

Melatonin has been detected in fruits, leaves, roots, and seeds of a considerable variety of plant species. Various methods, such as cyclodextrin-modified micellar electrokinetic chromatography, enzyme-linked immuno sorbent assay, radioimmunoassay (RIA), high-performance LC (HPLC), HPLCelectrochemical detection, HPLC-fluorescence detector, HPLCMS and HPLC-UV spectrophotometry (UV) can be applied in order to determine melatonin levels in plants.

The first step in determining the levels of melatonin in plants is to find the right extraction method, which have been tried by different authors. The first identification method of melatonin in plants was described by Van Tassel et al. ${ }^{93}$ in a congress communication in 1993. The authors had detected melatonin in tomato fruits (Solanum lycopersicum L.) by using RIA and gas chromatography attached with MS, but the results were not published extensively until 1995. ${ }^{94}$
Nowadays, most of the researchers have been utilizing liquid nitrogen treated-plant tissue, which were extracted with organic solvents such as methanol, chloroform, or ethyl acetate. Analysis of these extracts by LC and identification by MS are the most used and recommended techniques for the detection and quantification of melatonin in plants. Due to the developed technology of LC coupled to time-of-flight/MS has also been applied for the melatonin detection in recent years. ${ }^{95}$

\section{Biotechnology}

A biotechnologic study showed that transgenic plant rich on account of melatonin had more antioxidative activity and higer yield than regular plants. ${ }^{107-109}$ When activity of ASMT enzymecatalyzed from $\mathrm{N}$-acetylserotonin to melatonin and isolated firstly from rice in plants- was increased by overexpression, the level of melatonin has also increased..$^{110,111}$ A study demonstrated that since 6-hydroxymelatonin was not determined in rice, melatonin 2-hydroxylase has been dominant enzyme in melatonin production. ${ }^{112}$

\section{CONCLUSION}

Melatonin has been studied to treat some symptoms and diseases in human over the years. Melatonin supplements have proven significant results for treating insomnia and other circadian rhythms caused sleep disorders, morever, jet lag and shift work, headache, various cancers, gallbladder stones, tinnitus, rheumatoid arthritis, Alzheimer's disease, and psychiatric disorders have also tried to be eased with melatonin. Besides, it is known that melatonin is a powerful antioxidant and it improves the immune system. According to recent research, melatonin has also a great anti-aging effect.

Melatonin is a hormone that naturally produced by pineal glad in human brain especially at night-time, hovewer, smoking, using 
alcohol, excessive coffee consumption, some medications and disorders can suppress the production of the melatonin. Therefore melatonin should be taken externally such as synthetic melatonin supplements, or from natural resources which produce or contain melatonin. Furthermore, taking nutrients, which contain tryptophan, can increase the secretion of melatonin in the body. For instance, eating strawberries, apples, cherry/juice, rice, pistachios, almonds, spinach, cabbage, onions, tomatoes, cucumber, linseed and sunflower seeds, thistle, fenugreek and mustard; drinking teas such as fennel and anise tea.

In this study, our aim was to bring attention to melatonin in plants, which has important roles in plants as well as in animals. Many scientists have laboured to identify and quantify the levels of melatonin in plants. Although there are numbers of studies were completed in plants still more studies have been needed to analyse the levels and their absorption and efficiency of melatonin directly from plants, teas and pharmaceutical preparations.

Conflict of Interest: No conflict of interest was declared by the authors.

\section{REFERENCES}

1. Lerner AB, Case JD, Takahashi Y, Lee TH, Mori W. Isolation of melatonin, the pineal gland factor that lightens melanocytes. J Am Chem Soc. 1958;80:2587.

2. Nordlund JJ, Lerner AB. The effects of oral melatonin on skin color and on the release of pituitary hormones. J Clin Endocrinol Metab. 1977;45:768-774.

3. Heiligenstein E, Guenther G. Over-the-counter psychotropics: a review of melatonin, St John's wort, valerian, and kava-kava. J Am Coll Health. 1998:46:271-276

4. Murch SJ, KrishnaRaj S, Saxena PK. Tryptophan is a precursor for melatonin and serotonin biosynthesis in in vitro regenerated St. John's wort (Hypericum perforatum L. cv. Anthos) plants. Plant Cell Rep. 2000;19:698-704.

5. Reiter RJ, Tan DX. Melatonin: an antioxidant in edible plants. Ann N Y Acad Sci. 2002;957:341-344.

6. Delgado PL, Charney DS, Price LH, Aghajanian GK, Landis H, Heninger GR. Serotonin function and the mechanism of antidepressant action: reversal of antidepressant-induced remission by rapid depletion of plasma tryptophan. Arch Gen Psychiatry. 1990;47:411-418.

7. Taylor DL. Close-up on serotonin, Learn how this key neurotransmitter influences moods and behavior. Nursing. 1995;25:64.

8. Gern WA, Greenhouse SS. Examination of in vitro melatonin secretion from superfused trout (Salmo gairdneri) pineal organs maintained under die illumination or continuous darkness. Gen Comp Endocrinol. 1988;71:163-174.

9. Wehr TA. The durations of human melatonin secretion and sleep respond to changes in daylength (photoperiod). J Clin Endocrinol Metab. 1991;73:1276-1280.

10. Tan DX, Manchester LC, Hardeland R, Lopez-Burillo S, Mayo JC, Sainz RM, Reiter RJ. Melatonin: a hormone, a tissue factor, an autocoid, a paracoid, and an antioxidant vitamin. J Pineal Res. 2003;34:75-78.

11. Dubbels R, Reiter RJ, Klenke E, Goebel A, Schnakenberg E, Ehlers C, Schiwara $H W$, Schloot W. Melatonin in edible plants identified by radioimmunoassay and by high performance liquid chromatography-mass spectrometry. J Pineal Res. 1995;18:28-31.

12. Hardeland R, Balzer I, Poeggeler B, Fuhrberg B, Uría H, Behrmann G, Wolf $\mathrm{R}$, Meyer TJ, Reiter RJ. On the primary functions of melatonin in evolution:
Mediation of photoperiodic signals in a unicell, photooxidation, and scavenging of free radicals. J Pineal Res. 1995;18:104-111.

13. Reiter RJ, Tan DX, Manchester LC, Simopoulos AP, Maldonado MD, Flores LJ, Terron MP. Melatonin in edible plants (phytomelatonin): identification, concentrations, bioavailability and proposed functions. World Rev Nutr Diet. 2007; $97: 211-230$

14. Tan DX, Manchester LC, Reiter RJ, Qi WB, Karbownik M, Calvo JR. Significance of melatonin in antioxidative defense system: reactions and products. Biol Signals Recept. 2000;9:137-159.

15. Conti A, Conconi S, Hertens E, Skwarlo-Sonta K, Markowska M, Maestroni $\mathrm{JM}$. Evidence for melatonin synthesis in mouse and human bone marrow cells. J Pineal Res. 2000;28:193-202.

16. Cardinali DP, Rosner JM. Metabolism of serotonin by the rat retina in vitro. $J$ Neurochem. 1971;18:1769-1770.

17. Tosini $G$, Menaker M. The clock in the mouse retina: melatonin synthesis and photoreceptor degeneration. Brain Res. 1998;789:221-228.

18. Yin B, Li T, Li Z, Dang T, He P. Determination of Melatonin and Its Metabolites in Biological Fluids and Eggs Using High-Performance Liquid Chromatography with Fluorescence and Quadrupole-Orbitrap High-Resolution Mass Spectrometry. Food Anal Method. 2015;9:1-8.

19. Escriva L, Manyes L, Barbera M, Martinez-Torres D, Meca G. Determination of Melatonin in Acyrthosiphon pisum Aphids by Liquid Chromatography-Tandem Mass Spectrometry. J Insect Physiol. 2016;86:48-53.

20. Tan DX, Manchester LC, Terron MP, Flores LJ, Reiter RJ. One molecule, many derivatives: A never-ending interaction of melatonin with reactive oxygen and nitrogen species? J Pineal Res. 2007;42:28-42.

21. Rodriguez C, Mayo JC, Sainz RM, Antolin I, Herrera F, Martin V, Reiter RJ. Regulation of antioxidant enzymes: a significant role for melatonin. J Pineal Res. 2004;36:1-9.

22. Pandi-Perumal SR, Srinivasan V, Maestroni GJM, Cardinali DP, Poeggeler B, Hardeland R. Melatonin: Nature's most versatile biological signal? FEBS J. 2006;273:2813-2838

23. Korkmaz A, Reiter RJ, Topal T, Manchester LC, Oter S, Tan DX. Melatonin: an established antioxidant worthy of use in clinical trials. Mol Med. 2009;15:4350.

24. Romero A, Egea J, Garcia AG, Lopez, MG. Synergistic neuroprotective effect of combined low concentrations of galantamine and melatonin against oxidative stress in SH-SY5Y neuroblastoma cells. J Pineal Res. 2010;49:141148.

25. Um HJ, Kwon TK. Protective effect of melatonin on oxaliplatin-induced apoptosis through sustained Mcl-1 expression and anti-oxidant action in renal carcinoma Caki cells. J Pineal Res. 2010;49:283-290.

26. Goswami S, Haldar C. Melatonin as a possible antidote to UV radiation induced cutaneous damages and immune-suppression: An overview. J Photochem Photobiol B. 2015;153:281-288.

27. Matsubara E, Bryant-Thomas T, Pacheco Quinto J, Henry TL, Poeggeler B, Herbert D, Pappolla MA. Melatonin increases survival and inhibits oxidative and amyloid pathology in a transgenic model of Alzheimer's disease. $J$ Neurochem. 2003;85:1101-1108.

28. Feng Z, Chang Y, Cheng Y, Zhang BL, Qu ZW, Qin C, Zhang JT. Melatonin alleviates behavioral deficits associated with apoptosis and cholinergic system dysfunction in the APP 695 transgenic mouse model of Alzheimer's disease. J Pineal Res. 2004;37:129-136.

29. Hibaoui Y, Roulet E, Ruegg UT. Melatonin prevents oxidative stress-mediated mitochondrial permeability transition and death in skeletal muscle cells. J Pineal Res. 2009;47:238-252.

30. Hong Y, Palaksha KJ, Park K, Park S, Kim HD, Reiter RJ, Chang KT. Review Article: Melatonin plus exercise-based neurorehabilitative therapy for spinal cord injury. J Pineal Res. 2010;49:201-209. 
31. Sanchez-Barcelo EJ, Mediavilla MD, Tan DX, Reiter RJ. Clinical uses of melatonin: evaluation of human trials. Curr Med Chem. 2010;17:2070-2095.

32. Wirz-Justice A. Melatonin: a new wonder drug? Praxis (Bern 1994) 1996;85:1332-1336.

33. Reiter RJ. The melatonin rhythm: both a clock and a calendar. Experientia. 1993:49:654-664.

34. Zhdanova IV. Melatonin as a hypnotic: pro. Sleep Med Rev. 2005;9:51-65.

35. Thompson C, Mezey G, Corn T, Franey C, English J, Arendt J, Checkley SA. The effect of desipramine upon melatonin and cortisol secretion in depressed and normal subjects. Br J Psychiatry. 1985;147:389-393.

36. Rao AV, Devi SP, Srinivasan V. Urinary melatonin in depression. Indian J Psychiatry. 1983;25:167-172.

37. Srinivasan V, Smits M, Spence W, Lowe AD, Kayumov L, Pandi-Perumal SR, Cardinali DP. Melatonin in mood disorders. World J Biol Psychiatry. 2006;7:138-151.

38. Carrillo-Vico A, Garcia-Perganeda A, Naji L, Calvo JR, Romero MP, Guerrero JM. Expression of membrane and nuclear melatonin receptor mRNA and protein in the mouse immune system. Cell Mol Life Sci. 2003;60:2272-2278.

39. Maestroni GJ. The immunoneuroendocrine role of melatonin. J Pineal Res. 1993;14:1-10.

40. Garcia-Maurino S, Gonzalez-Haba MG, Calvo JR, Rafii-El-Idrissi M, SanchezMargalet V, Goberna R, Guerrero JM. Melatonin enhances IL-2, IL-6, and IFN-gamma production by human circulating CD4+ cells: a possible nuclear receptor-mediated mechanism involving $T$ helper type 1 lymphocytes and monocytes. J Immunol. 1997;159:574-581.

41. Garcia-Maurino S, Pozo D, Carrillo-Vico A, Calvo JR, Guerrero JM. Melatonin activates Th1 lymphocytes by increasing IL-12 production. Life Sci. 1999:65:2143-2150.

42. Puig A, Rancan L, Paredes SD, Carrasco A, Escames G, Vara E, Tresguerres JA. Melatonin decreases the expression of inflammation and apoptosis markers in the lung of a senescence-accelerated mice model. Exp Gerontol. 2016;75:1-7.

43. Mosinska P, Socala K, Nieoczym D, Laudon M, Storr M, Fichna J, Wlaz P. Anticonvulsant activity of melatonin, but not melatonin receptor agonists Neu-P11 and Neu-P67, in mice. Behav Brain Res. 2016;307:199-207.

44. Ting KN, Blaylock NA, Sugden D, Delagrange P, Scalbert E, Wilson VG. Molecular and pharmacological evidence for MT1 melatonin receptor subtype in the tail artery of juvenile Wistar rats. Br J Pharmacol. 1999;127:987-995.

45. Sainz RM, Mayo JC, Rodriguez C, Tan DX, Lopez-Burillo S, Reiter RJ. Melatonin and cell death: differential actions on apoptosis in normal and cancer cells. Cell Mol Life Sci. 2003;60:1407-1426.

46. Blask DE, Dauchy RT, Sauer LA. Putting cancer to sleep at night: the neuroendocrine/circadian melatonin signal. Endocrine. 2005;27:179-188.

47. Reiter RJ, Tan DX, Fuentes-Broto L. Melatonin: a multitasking molecule. Prog Brain Res. 2010;181:127-151.

48. Shiu SY. Towards rational and evidence-based use of melatonin in prostate cancer prevention and treatment. J Pineal Res 2007;43:1-9.

49. Tamarkin L, Danforth D, Lichter A, DeMoss E, Cohen M, Chabner B, Lippman $M$. Decreased nocturnal plasma melatonin peak in patients with estrogen receptor positive breast cancer. Science 1982;216:1003-1005.

50. Danforth DN, Tamarkin L, Lippman ME. Melatonin increases oestrogen receptor binding activity of human breast cancer cells. Nature. 1983;305:323325.

51. Blask DE, Wilson ST, Zalatan F. Physiological melatonin inhibition of human breast cancer cell growth in vitro: evidence for a glutathione-mediated pathway. Cancer Res. 1997;57:1909-1914.

52. Sanchez-Barcelo EJ, Cos S, Fernandez R, Mediavilla MD. Melatonin and mammary cancer: a short review Endocr Relat Cancer. 2003;10:153-159.
53. Blask DE, Sauer LA, Dauchy RT. Melatonin as a chronobiotic/anticancer agent: cellular, biochemical, and molecular mechanisms of action and their implications for circadian-based cancer therapy. Curr Top Med Chem. 2002;2:113-132.

54. Srinivasan V, Spence DW, Moscovitch A, Pandi-Perumal SR, Trakht I, Brown GM. Cardinali DP. Malaria: therapeutic implications of melatonin. J Pineal Res. 2010;48:1-8.

55. Poeggeler B, Balzer I, Fischer J, Behrmann G, Hardeland R. A role of melatonin in dinoflagellates? Acta Endocrinol-Cop 1989;120(3 Supp l):97.

56. Balzer I, Hardeland R. Stimulation of bioluminescence by 5-methoxylated indoleamines in the dinoflagellate, Gonyaulax polyedra. Comp Biochem Phys C. 1991;98:395-397.

57. Hardeland R. The presence and function of melatonin and structurally related indoleamines in a dinoflagellate, and a hypothesis on the evolutionary significance of these tryptophan metabolites in unicellulars. Experientia. 1993;49:614-622.

58. Fuhrberg B, Balzer I, Hardeland R, Werner A, Lüning K. The vertebrate pineal hormone melatonin is produced by the brown alga Pterygophora californica and mimics dark effects on growth rate in the light. Planta. 1996;200:125-131.

59. Murch SJ, Simmons CB, Saxena PK. Melatonin in feverfew and other medicinal plants. Lancet. 1997;350:1598-1599.

60. Hardeland R. Melatonin and 5-methoxytryptamine in non-metazoans. Reprod Nutr Dev. 1999;39:399-408.

61. Hattori A, Migitaka H, ligo M, Itoh M, Yamamoto K, Ohtani-Kaneko R, Reiter RJ. Identification of melatonin in plants and its effects on plasma melatonin levels and binding to melatonin receptors in vertebrates. Biochem Mol Biol Int. 1995;35:627-634.

62. Van Tassel DL, Roberts N, Lewy A, O'Neill SD. Melatonin in plant organs. J Pineal Res. 2001;31:8-15.

63. Cao J, Murch SJ, O'Brien R, Saxena PK. Rapid method for accurate analysis of melatonin, serotonin and auxin in plant samples using liquid chromatographytandem mass spectrometry. J Chromatogr A. 2006;1134:333-337.

64. Tan DX, Manchester LC, Di Mascio P, Martinez GR, Prado FM, Reiter RJ. Novel rhythms of N1-acetyl-N2-formyl-5-methoxykynuramine and its precursor melatonin in water hyacinth: importance for phytoremediation. FASEB J. 2007:21:1724-1729.

65. Arnao MB, Hernandez-Ruiz J. The physiological function of melatonin in plants. Plant Signal Behav. 2006;1:89-95.

66. Kang K, Kong K, Park S, Natsagdorj U, Kim YS, Back K. Molecular cloning of a plant $\mathrm{N}$-acetylserotonin methyltransferase and its expression characteristics in rice. J Pineal Res. 2011;50:304-309.

67. Arnao MB, Hernandez-Ruiz J. Melatonin promotes adventitious-and lateral root regeneration in etiolated hypocotyls of Lupinus albus L. J Pineal Res. 2007:42:147-152.

68. Tan DX, Manchester LC, Helton P, Reiter RJ. Phytoremediative capacity of plants enriched with melatonin. Plant Signal Behav. 2007;2:514-516.

69. Kolar J, Johnson CH, Machackova I. Presence and possible role of melatonin in a short-day flowering plant, Chenopodium rubrum. Adv Exp Med Biol. 1999;460:391-393.

70. Shi H, Qian Y, Tan DX, Reiter RJ, He C. Melatonin induces the transcripts of CBF/DREB1s and their involvement in both abiotic and biotic stresses in Arabidopsis. J Pineal Res. 2015;59:334-342.

71. Kolodziejczyk I, Dzitko, K, Szewczyk R, Posmyk MM. Exogenous melatonin improves corn (Zea mays L.) embryo proteome in seeds subjected to chilling stress. J Plant Physiol. 2016;193:47-56.

72. Dawood MG, El-Awadi ME. Alleviation of salinity stress on Vicia faba L. plants via seed priming with melatonin. Acta Biolo Colomb. 2015;20:223-235. 
73. Badria FA. Melatonin, serotonin, and tryptamine in some Egyptian food and medicinal plants. J Med Food. 2002;5:153-157.

74. Kolar J, Machackova I. Melatonin in higher plants: occurrence and possible functions. J Pineal Res. 2005;39:333-341.

75. Tan DX, Hardeland R, Manchester LC, Paredes SD, Korkmaz A, Sainz RM, Reiter RJ. The changing biological roles of melatonin during evolution: from an antioxidant to signals of darkness, sexual selection and fitness. Biol Rev Camb Philos Soc. 2010;85:607-623.

76. Wei W, Li QT, Chu YN, Reiter RJ, Yu XM, Zhu DH, Chen SY. Melatonin enhances plant growth and abiotic stress tolerance in soybean plants. J Exp Bot. 2015;66:695-707.

77. Zhang N, Sun Q, Zhang H, Cao Y, Weeda S, Ren S, Guo YD. Roles of melatonin in abiotic stress resistance in plants. J Exp Bot. 2015;66:647-656.

78. Liu J, Wang W, Wang L, Sun Y. Exogenous melatonin improves seedling health index and drought tolerance in tomato. Plant Growth Regul. 2015;77:317-326.

79. Li H, He J, Yang X, Li X, Luo D, Wei C, Ma J, Zhang Y, Yang J, Zhang X. Glutathione-dependent induction of local and systemic defense against oxidative stress by exogenous melatonin in cucumber (Cucumis sativus L.). J Pineal Res. 2016;60:206-216.

80. Hernandez IG, Gomez FJV, Cerutti S, Arana MV, Silva MF. Melatonin in Arabidopsis thaliana acts as plant growth regulator at low concentrations and preserves seed viability at high concentrations. Plant Physiol Biochem. 2015;94:191-196.

81. Zhao H, Su T, Huo L, Wei H, Jiang Y, Xu L, Ma F. Unveiling the mechanism of melatonin impacts on maize seedling growth: sugar metabolism as a case. $J$ Pineal Res. 2015;59:255-266.

82. Reiter RJ, Tan DX, Zhou Z, Cruz MHC, Fuentes-Broto L, Galano A. Phytomelatonin: assisting plants to survive and thrive. Molecules. 2015;20:7396-7437.

83. Vitalini S, Gardana C, Simonetti P, Fico G, Iriti M. Melatonin, melatonin isomers and stilbenes in Italian traditional grape products and their antiradical capacity. J Pineal Res. 2013;54:322-333.

84. Yilmaz C, Kocadagli T, Gokmen V. Formation of melatonin and its isomer during bread dough fermentation and effect of baking. J Agric Food Chem. 2014;62:2900-2905.

85. Iriti M, Vigentini I. Tryptophan-ethylester, the false (unveiled) melatonin isomer in red wine. Int J Tryptophan Res. 2015;8:27-29.

86. Nilsson LM, Johansson I, Lenner P, Lindahl B, Van Guelpen B. Consumption of filtered and boiled coffee and the risk of incident cancer: a prospective cohort study. Cancer Causes Control. 2010;21:1533-1544.

87. Park CH, Myung SK, Kim TY, Seo HG, Jeon YJ, Kim Y. Coffee consumption and risk of prostate cancer: a meta-analysis of epidemiological studies. BJU Int. 2010;106:762-769.

88. Yu X, Bao Z, Zou J, Dong J. Coffee consumption and risk of cancers: a metaanalysis of cohort studies. BMC Cancer 2011;11:96.

89. Tan DX, Hardeland R, Manchester LC, Korkmaz A, Ma S, Rosales-Corral $\mathrm{S}$, Reiter RJ. Functional roles of melatonin in plants, and perspectives in nutritional and agricultural science. J Exp Bot 2012;63:577-597.

90. Chen G, Huo Y, Tan DX, Liang Z, Zhang W, Zhang Y. Melatonin in Chinese medicinal herbs. Life Sci. 2003;73:19-26.

91. Iriti M, Varoni EM. Melatonin in Mediterranean diet, a new perspective. J Sci Food Agric. 2015;95:2355-2359.

92. Cerezo AB, Leal A, Alvarez-Fernandez MA, Hornedo-Ortega R, Troncoso AM, Garcia-Parrilla MC. Quality control and determination of melatonin in food supplements. J Food Comp Anal. 2016;45:80-86.
93. Van Tassel D, Li J, O’Neill S. Melatonin-identification of a potential dark signal in plants. Plant Physiol. 1993;102:117-117.

94. Van Tassel D, Roberts N, O'Neill S. Melatonin from higher plants: isolation and identification of $\mathrm{N}$-acetyl-5-methoxytryptamine. Plant Physiol. 1995;108:101101.

95. Arnao MB. Phytomelatonin: Discovery, content, and role in plants. Advances in Botany. 2014;11:2014.

96. Zohar R, Izhaki I, Koplovich A, Ben-Shlomo R. Phytomelatonin in the leaves and fruits of wild perennial plants. Phytochem Lett. 2011;4:222-226.

97. Manchester LC, Tan DX, Reiter RJ, Park W, Monis K, Qi W. High levels of melatonin in the seeds of edible plants: possible function in germ tissue protection. Life Sci. 2000;67:3023-3029.

98. Gomez FJ, Hernández IG, Cerutti S, Silva MF. Solid phase extraction/ cyclodextrin-modified micellar electrokinetic chromatography for the analysis of melatonin and related indole compounds in plants. Microchem $\mathrm{J}$. 2015;123:22-27.

99. Hernández-Ruiz J, Arnao MB. Melatonin stimulates the expansion of etiolated lupin cotyledons. Plant Growth Regul. 2008;55:29-34.

100. Hernández-Ruiz J, Cano A, Arnao MB. Melatonin: a growth-stimulating compound present in lupin tissues. Planta. 2004:220:140-144.

101. Reiter RJ, Manchester LC, Tan DX. Melatonin in walnuts: influence on levels of melatonin and total antioxidant capacity of blood. Nutrition. 2005;21:920-924.

102. Hernandez-Ruiz J, Cano A, Arnao MB. Melatonin acts as a growth-stimulating compound in some monocot species. J Pineal Res. 2005;39:137-142.

103. Jinying W, Chuan J, Shuke L, Jingui Z. Study on analysis method of melatonin and melatonin content in corn and rice seeds. Chinese Agricultural Science Bulletin. 2009;17:6.

104. Gonzalez-Gomez D, Lozano M, Fernandez-Leon MF, Ayuso MC, Bernalte $\mathrm{MJ}$, Rodriguez $\mathrm{AB}$. Detection and quantification of melatonin and serotonin in eight sweet cherry cultivars (Prunus avium L.). Eur Food Res Technol. 2009;229:223-229.

105. Burkhardt S, Tan DX, Manchester LC, Hardeland R, Reiter RJ. Detection and quantification of the antioxidant melatonin in Montmorency and Balaton tart cherries (Prunus cerasus). J Agric Food Chem. 2001;49:4898-4902.

106. Kirakosyan A, Seymour EM, Llanes DEU, Kaufman PB, Bolling SF. Chemical profile and antioxidant capacities of tart cherry products. Food Chem. 2009;115:20-25.

107. Hardeland R, Poeggeler B. Non-vertebrate melatonin, J Pineal Res. 2003;34:233-241.

108. $X u X D$, Sun $Y$, Guo $X Q$, Sun $B$, Zhang J. Effects of exogenous melatonin on ascorbate metabolism system in cucumber seedlings under high temperature stress. Ying Yong Sheng Tai Xue Bao. 2010;21:2580-2586.

109. Okazaki M, Higuchi K, Aouini A, Ezura H. Lowering intercellular melatonin levels by transgenic analysis of indoleamine 2, 3-dioxygenase from rice in tomato plants. J Pineal Res. 2010;49:239-247.

110. Byeon Y, Park S, Lee HY, Kim YS, Back K. Elevated production of melatonin in transgenic rice seeds expressing rice tryptophan decarboxylase. J Pineal Res. 2014;56:275-282.

111. Byeon Y, Lee HJ, Lee HY, Back K. Cloning and functional characterization of the Arabidopsis $\mathrm{N}$-acetylserotonin 0-methyltransferase responsible for melatonin synthesis. J Pineal Res. 2016;60:65-73.

112. Byeon Y, Tan DX, Reiter RJ, Back K. Predominance of 2-hydroxymelatonin over melatonin in plants. J Pineal Res. 2016;60:65-73. 